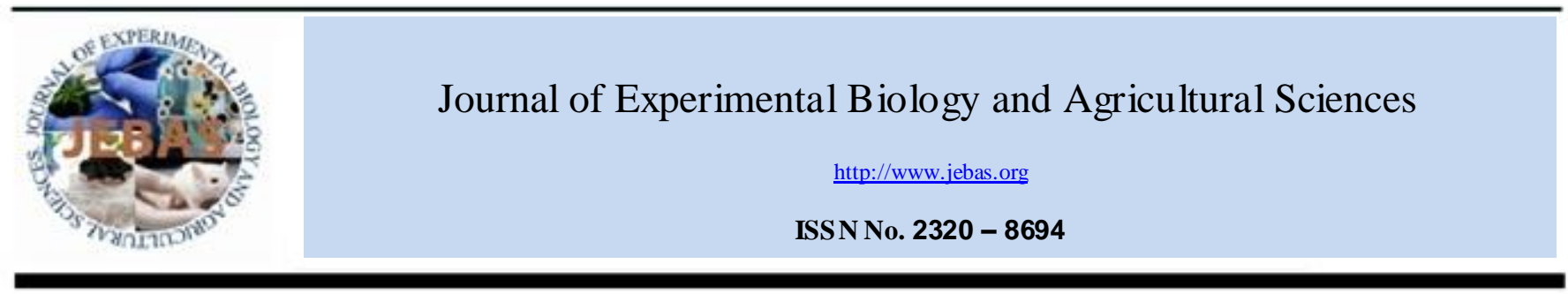

\title{
IMPACT OF THE CULTURAL ROOTS OF THE WILD CHILLI "PIQUÍN" (Capsicum annuum L. var. glabriusculum) IN THE NORTHEAST OF MEXICO
}

\section{Villalón-Mendoza Horacio ${ }^{1, *}$, Ramírez-Meráz Moisés ${ }^{2}$, Luna-Ruíz José de Jesús ${ }^{3}$, Garza-Ocañas Fortunato ${ }^{1}$ and Artemio Carrillo-Parra ${ }^{1}$}

\footnotetext{
${ }^{1}$ Universidad Autónoma de Nuevo León, Facultad de Ciencias Forestales, A.P. 41, C.P. 67700 Linares, N. L., México.

${ }^{2}$ Instituto Nacional de Investigaciones Forestales, Agrícolas y Pecuarias - Centro de Investigación Regional Noreste

${ }^{3}$ Universidad Autónoma de Aguascalientes, Centro de Ciencias Agropecu arias.
}

Received - March 18, 2015; Revision - March 25, 2015; Accepted - May 18, 2015

Available Online - June 19, 2015

DOI: http://dx.doi.org/10.18006/2015.3(3).226.231

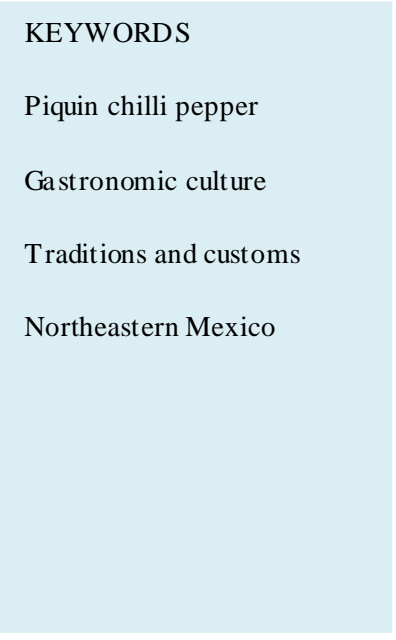

\begin{abstract}
ABSTRAC T
The chilli peppers "piquin" (C. annuum L. var. glabriusculum) is a wild species of northeastern Mexico, it has an important role in the historical and regional development. The objective of the present investigation was to identify and assess the impact of wild chilli "piquin" roots cultural on the northeastern Mexican population and its historical prospects among the population. Data were generated with the help of a well documented survey and results obtained from the survey were statistically analysis at $\mathrm{p} \leq 0.05$. Results of the study revealed that $74 \%$ population of the of the study area consumed chilli (piquin) fruits almost entire year by using the techniques of fruits preservation. Results of the study strongly recommended that there is a need to protect the nat ural resources of the northeastern Mexico. Strategies should generate for improving ecological awareness in collectors for the management of the specie. The price of per kilogram chilli fruit is depends on the amount of fruit collected per day by the people, climatic conditions and season of the year some time prices can be reached up to US\$ 85 per $\mathrm{kg}$ of fresh fruit in the month of April. The participation of females was reported very low in the productive processes or value chain of the piquin chilli peppers in the rural area of Northeastern Mexico.
\end{abstract}

* Corresponding author

E-mail: horacio.villalonmn@uanl.edu.mx (Villalón -Mendoza Horacio)

Peer review under responsibility of Journal of Experimental Biology and Agricultural Sciences.

Production and Hosting by Horizon Publisher (www.my-

vision.webs.com/horizon.html).

All rights reserved.
All the article published by Journal of Experimental Biology and Agricultural Sciences is licensed under a Creative Commons Attribution-NonCommercial 4.0 International License Based on a work at www.jebas.org.

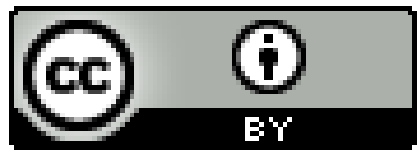




\section{Introduction}

Mexico is worldwide known for maize, beans and condiments like chilli and its different varieties. Chilli pepper has an important place in Mexican culture and data of it consumption is available from precolumbian times and currently consumed in all the strata of Mexican society. High diversity of agroecological environments favors the domestication of this crop. The northeastern Mexico has framed with arid and semi-arid areas and these regions are dominated for the cultivation of wild chilli (García, 1983).

Historically, humans were created for extraction of resources from their nat ural habitat, in addition to represent additional income for the family economy peasant; also the cultural expression of a long process of mans interaction with the environment (Medina, 2010). The piquin chilli peppers represents a natural and cultural resource typical of northeastern Mexico. This plant as a component of the scrubland reported in the tropical and subtropical areas of Maxico. Wild chilli paper is known by various names in various Mexican ethnic groups the most popularly known one is the "piquin chilli peppers" while other names like "chilli of the field", "chilli del monte" are also common among the other peoples. These various names represents an important chapter of the history, culture and tradition of Mexico. Since its consumption data are available from the pre-hispanic times and it can be considered as the nearest ancestor to hot peppers Capsicum annuum, cultivated around the world (Pérez, 2009; Villalon-Mendoza et al., 2014). With regard to the nature of the collection activity of chilli, it is clear that participate of the social groups with a high degree of marginalization and little organizational integration for the production (Medina et al., 2003).

Wild chilli peppers "piquin" (C. annuum L. var. glabriusculum) has a wide range of shapes, colors, aromas, flavors and sizes and because of this it has valuable contribution for the development of gastronomic value for Mexican population (Pozo \& Ramírez, 2003). The species has creamy white flower with oval shaped fruits, fruit has 5 to 7 $\mathrm{mm}$ diameter with stalks and grow solitarily. At maturity fruits color changed from green to orange or red color with an average of 18 seeds per fruit (Jurado et al., 2000; González et al., 2009; Pérez et al., 2009; Aguilar-Rincón et al., 2010; Villalón-Mendoza et al., 2013).

Wild chilli peppers (piquin) shows the superiority over the other kinds of chilli by its pleasant flavor and degree of pungency. This wild chilli of the northeast of Mexico is a very spicy chilli, but its characteristic flavor is very much appreciated by consumer and because of this it pays $30-340$ times more value then commercial chillies cultivated, as the "Serrano" or "Jalapeno". Moreover, it does not irritate the digestive system. Wild chilli "piquín" has an economic potential for the rural environment and it strongly rooted in regional gastronomy and hence considered as an important species in Northeastern Mexico. The demand of the piquin chilli peppers and its socio-economic importance as a natural resource, primarily in rural areas, make the species with potential for its production, becoming an alternative to in situ conservation ex situ and productive in a sustainable manner (Villalón-Mendoza et al., 2014). The chilli peppers were put up his represents as a food source, medicinal and incomegenerating (Medina-Martinez, 2007). This species is consumed in all seasons and it becomes important source of diet. People consumed it either fresh or dried in fresh form it be use green or red forms. It can be consumed in salads, sauces, pickles, moles, mixtures to marinate meats, chilli cheese etc forms. The "piquín" chilli pepper is transformed into finished goods for sale e.g. sauce and it has an economic potential in the domestic and international market (Almanza, 1993; Ramírez-Meráz et al., 2015).

From the ecological point of view, the current management practices of northeastern Mexican biotic resources might affect the future membership of the wild chilli and can reduce its genetic potential (Villalon et al., 2009). This species under natural condition entirely depends on the environmental factors such as soil, altitude, rainfall, evaporation and temperatures. From social point of view, it has been estimated that $15 \%$ of the northeastern Mexican rural population dedicated to collect wild chilli peppers, the harvesting time for this chilli is September to December, during this period $60 \%$ of the income earned by these communities through the collection and sale of this wild chilli and chilli based product. This activity related to the wild chilli cultivation and collection was specially performed by women and children; occasionally the male producer enters in this process (Medina, 2010).

From an economic point of view, their marketing comes mainly from collections of wild populations, which mostly harvest without a plan for the sustainable management, generating a deterioration of the ecosystem and the natural banks of germplasm (Perez, 2009), coupled with the difficulty of seed germination. The objective of the present investigation was to identify and assess the impact of the historical process on the preference and cultural roots of the wild piquin chilli peppers (Capsicum annuum L. var. glabriusculum) in the northeastern Mexican population and for analyzing its role in the strengthening the lifestyle of these peoples.

\section{Materials \& Methods}

Present study was conducted in the northeastern Mexico, to determine the preference of wild chilli consumption and to establish its cultural relationship with inhabitants with this wildlife resource. Surveys were designed to confirm the above said fin dings with the help of simple easily answerable items which helps in reducing time and costs of the field work. For capturing the proper and quality information previously trained interviewers were selected for the study. The questioner was contained following question: a) Do you consume wild chilli? b) How to preserve the wild chilli? c) What is the nutritional 
process you follow to preserve the wild chilli? d) How much are you willing to pay for a kilogram of wild chilli? e) Which is the reason?

To know the number of required necessary surveys and obtain a sampling that will yield statistically significant $(\mathrm{p} \leq 0.05)$ information it was necessary to perform a pre-sampling by applying the following formula (Rojas, 1998): $\mathrm{n}=\left(\mathrm{p} * \mathrm{q} * \mathrm{Z}^{2}\right) / \mathrm{E}^{2}$

Where; $\mathrm{n}=$ number of surveys needed for the study, $\mathrm{p}=$ proportion of affirmative answers, $\mathrm{q}=$ proportion of negative answers, $\mathrm{Z}=$ confidence level (95\%; with a value of 1.96 in areas under the normal curve), E= level of accuracy (0.05)

Above mentioned formula has been applied to the results of the pre-sampling and it was determined that total 297 surveys required for the present study and it was to the complementation of the surveys required for sampling in the field. The majority of surveys $(78 \%$ ) were conducted in metropolitan areas in the northeast of Mexico (Coahuila, Nuevo León and Tamaulipas) and a lower proportion (22\%) in municipalities of the rural area. Entire captured information from the field study were analyzed with the help of Excel program based Statistics 7 .

\section{Results}

It was reported that $74 \%$ of the northeastern Mexican population consumed wild chilli "piquin" fruit throughout the year fruits, it can be used either fresh at homes or can be store dry, frozen, or conserve it in sauces, brine or vinegar (Figure $1)$.

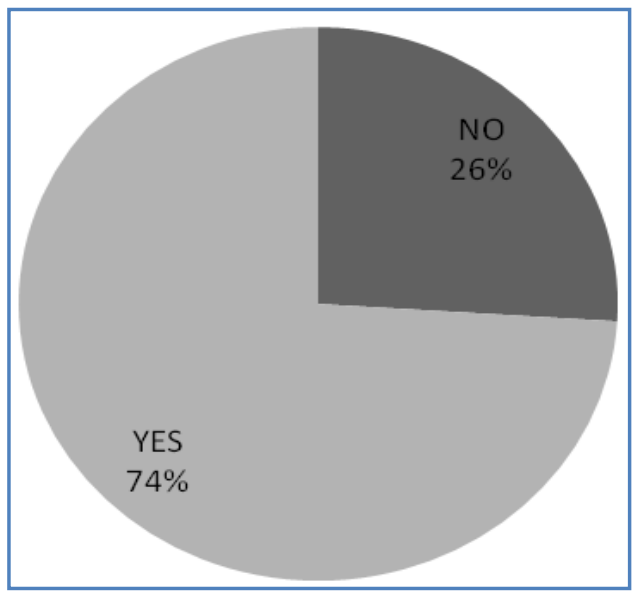

Figure 1 Percentage of families that used wild chilli peppers as part of their typical diet throughout the year.

Among the surveyed responded, 78 percent of the families used only one type of wild chilli "piquin" presentation in their homes while 14 percent of the respondent had two types of presentation. This was followed by the percentage of respondent $(5 \%)$ who used three types of presentation. The questioner based on the food preparation suggested that 29 percent of the respondent used it at home in dehydrated "piquin" chilli form while 27 percent respondent keeps it frozen. 44 percent of the respondent used it as processed products such as salsa ( 23 percent) or in brine ( 21 percent). The price that paid by respondent for "piquin" chilli is significantly higher than the other types chillies of chilli cultivars (Figure 2).

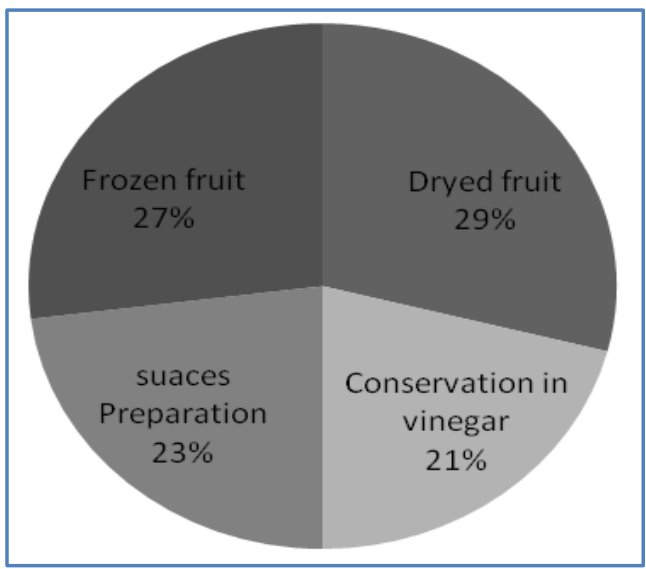

Figure 2 Types of food products prepared from wild chilli peppers with their respective frequencies of use throughout the year by northeastern Mexican families.

As shown in Figure 3 on average people paid around US \$12.6 per kilogram for wild chilli "piquin", with a standard deviation of US \$7.6 when the "Serrano" and "jalapeño" chilli peppers US $\$ 0.25$.

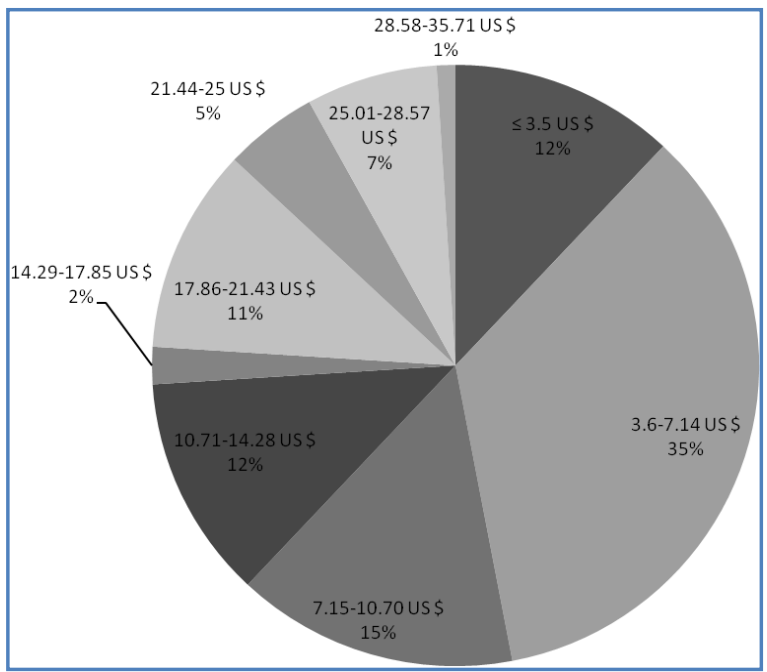

Figure 3 Represents the relationship of the willingness to pay in the ranges of the different prices in US dollars.

It was reported that the people of the northeastern Mexico offer more money for the wild chilli "piquin" than for any other commercial chilli, because they believe that it is a product of better taste and quality. Furthermore, respondent recognize the hard work required for the production of wild chilli product as well as a regional resource with which they identify culturally (Figure 4). 
The price of the per kilogram of wild chilli is a index of the amount of fruit collected per day by the people, which in turn, depend on the climatic conditions and season of the year concerned. It is complicated consideration that women's participation in the productive processes or value chain of the wild chilli is higher and it helps in the increasing the family income.

Result of the study revealed that there is a strong need for the protection of this natural resources in northeastern Mexico. Developments of strong strategies that generate ecological awareness in the collectors are required on the priority basis and there should be strong legislation for the management and sustainability of this species.

\section{Discussion and conclusions}

Present investigation highlighted the importance of wild chilli in northeastern Mexico and focused on the needs its conservation. According to the Medina et al. (2000) and Gaona et al. (2003) strong risk is associated with the collection of the wild chilli fruit from the field conditions because it is the part of food chain of many birds (Minus poliglottos and Toxostoma longirostre) and these birds are the part of the food chain of rattlesnakes (Crotalus atrox) but people collect the fruit of this chilli paper directly from the field and always encounter with the above said risks for the family income and subsistence. Cultivation of these under the backyard and green house condition protect the collector from the risk associated with the collection of this crop. Findings of the present study are supported by the findings of Medina (2010). It was reported that 38 percent of the collectors harvest this product by cutting the fruit bunches of the branches these type of activities are against the sustainable management of natural populations as mentioned Almanza (1993), can be in a near future bring irreversible consequences to miss genetic potential of these natural populations.

It was reported that various preparation of wild chilli peppers were use throughout the year by Mexican population, it was also reported that these settlers make several dishes by the processing and drying the fruit, the most common used (24 percent) of the chilli was the wiping in the shade and a third of them hanging from the branches by blotting with fruits down and at the top of the hearth of the kitchen where it sometimes reaches the smoke of the fire for cooking. Similar values to reach the 25 percent mentioned Medina, (2010) and VillalónMendoza et al. (2014). Frozen fruit was used by 22 percent consumers throughout years. Furthermore, 18 percent of the cultivars harvest it directly from their gardens while 17 percent were preserved it in vinegar (escabeche) and 17 percent used it in sauces. Finally 2 percent of the consumers consumed it fresh.

Present investigation was carried out to determine the behavior of the wild chilli pepper market, due to which it can carried out productive activities designed to meet the demands of quality of this product and use sustainably the value that represents this remedy which goes from the economic value to the sociocultural passing by the productive ecological and technical, so also reported Villalon-Mendoza et al. (2014).

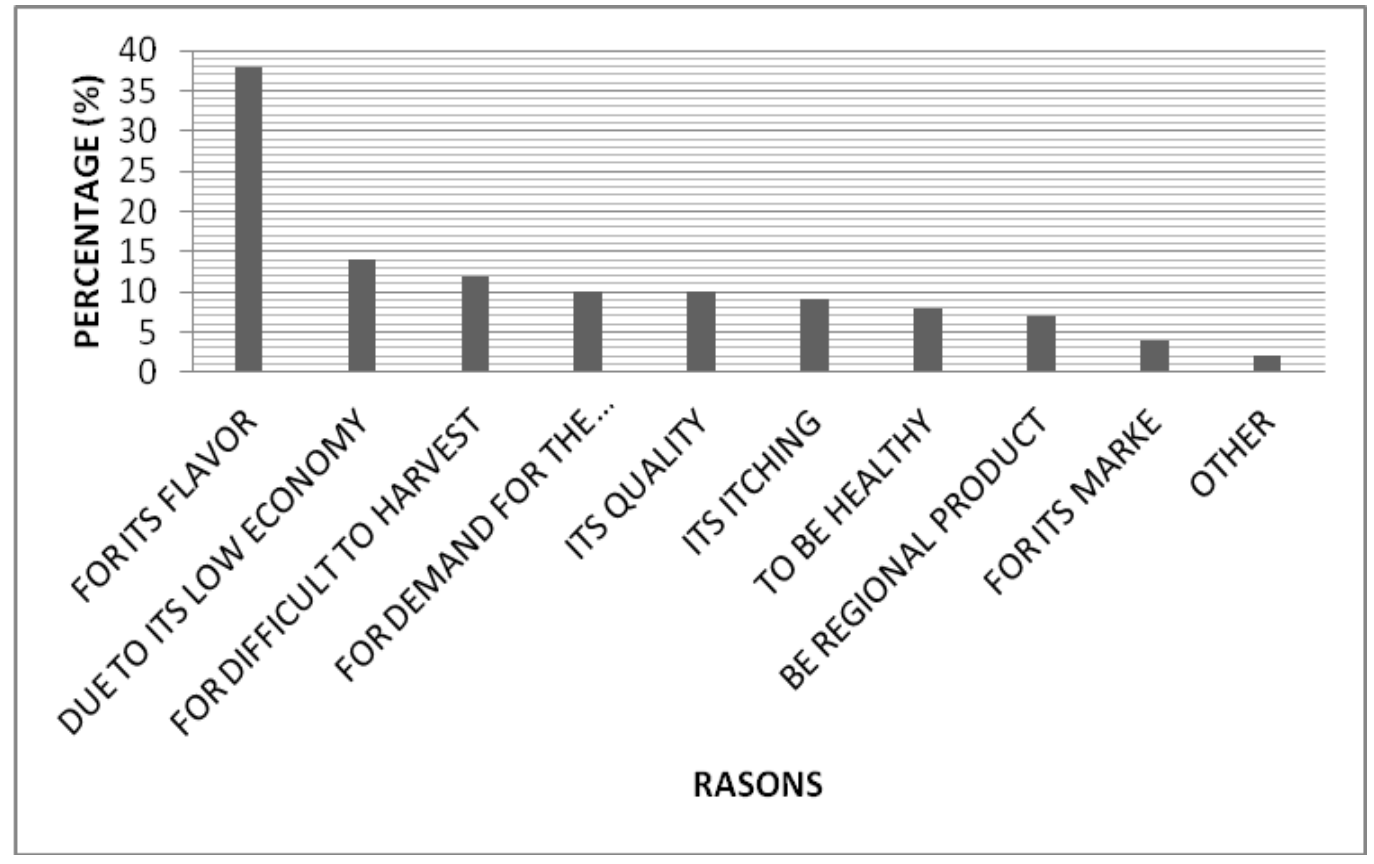

Figure 4 Reasons of consumers' preference regarding the use of wild chilli “piquin” in Northeastern Mexico. 
The results of the study suggested that the residents of the northeast of Mexico are ready to pay a high price for one kilogram of chilli, which predominates in amounts ranging from $\$ 3.60$ - \$7.10 US dollar with the 35 per cent, in line with $\$ 7.11$ - \$10.71 US dollar with the 15 percent. It was also reported that people are willing to pay higher price even it was reported that some respondents used to get price up to \$85 US dollar for every $\mathrm{kg}$ for green fresh wild chilli peppers and up to $\$ 180$ US dollar the kg of dry red fruit. Furthermore, Secretaría de Economía (2005) reported the prices of per ounce (conservation in vinegar; "escabeche") was \$3.1 US dollar in the market of the United States of America.

It was noted that the reasons for which people are willing to pay high price for the fruits of piquin chilli peppers are greater predominance ( 38 percent of those surveyed), pleasant flavor that presents the fruit of this product and with which are fully identified, followed by a low economy that people have with a 14 percent (referring to pay a low price by lack of economic resources, but aware of what is worth much more to them the fruit of chilli peppers). Similar result was reported by VillalonMendoza et al. (2014), where the preference of chilli used was the taste. Then it turned out that pay more than the piquin chilli peppers (12 percent), for the work that harvesting costs, including the risk of going to the field to harvest, this coincides with what was mentioned by Villalon et al. (2013), those who claim that this species has very small fruits, making it difficult harvest and quantity of fruit harvested by hand per hour. With equal proportion (10 percent), it was noted the quality of the product and by supply and demand. By its characteristic itch the mentioned the 9 percent of the respondents and by considering it very healthy (more than the other commercial chillies; "serrano" and "jalapeño") mentioned the 8 percent. It is worth mentioning that the 7 percent of the population of northeastern Mexico appreciates it and pays for being a regional product. Finally other causes are advantage of the excellent market that presents this product and resell to retail, buying wholesale and selling retail (4 percent) and to give a value added (in making sauces, preserves, etc.) in 2 percent.

It was confirmed by the findings of Medina (2010) those have reported that the harvesting is traditionally handmade and production can be sold for consumption in fresh or carry out productive activities of transformation to give added value to the product, the latter being activity that brings the best economic impacts to the producers of the field in Northeastern Mexico.

There is a greater need for protection of the natural resources of the northeastern Mexico, looking for strategies that generate ecological awareness in the collectors and legislation for the management and sustainability of the species. The price of the kilogram of wild chilli is indexed to the amount of fruit collected per day by the people, which in turn, depend on the climatic conditions of the season of the year concerned, coinciding with García (1983), Pérez (2009) and VillalonMendoza et al. (2014).

Journal of Experimental Biology and Agricultural Sciences http://www.jebas.org
The problem associated with the increasing the value added production of chilli and this thing enters the women in the productive chain; this made the things difficult since historically in the field is governed by a family organization of patriarchy. In general, the fear of the heads of family was that the women arrive to empower and with this man can lose its status within the family and community, by what normally chose to make sales directly from the fresh product, where they (the men) have the economic control, as similarly as mentioned Villalon- Mendoza et al., (2014) the productive system, without import leave to win a considerable economic potential.

\section{Conflict of interest}

Authors would hereby like to declare that there is no conflict of interests that could possibly arise.

\section{References}

Aguilar-Rincón VH, Corona-Torres T, López-López P, Latournerie-Moreno L, Ramírez-Meráz M, Villalón-Mendoza H, Aguilar-Castillo JA (2010) Los chiles de México y su distribución. SINAREFI, Colegio de Postgraduados, INIFAP, IT-Conkal, UANL, UAN. Montecillo, Texcoco, Estado de México.

Almanza FJG (1993) El chile piquín (Capsicum annuum L. var. aviculare Dieb) Estudio etnobotánico, biología y productividad. Bachelor Thesis submitted to Faculty of Biology. Universidad Autónoma de Nuevo León, México.

Gaona GG, Lara VM, Medina MT, Rodríguez BLA (2003) Entomofauna asociada al chile piquín (Capsicum annuum var. aviculare) en Tamaulipas. I.er Simposio Regional sobre Chile Piquín: Avances de Investigación en Tecnología de Producción Uso Racional del Recurso Silvestre. INIFAP. Río Bravo, Tamaulipas, México.

García JA (1983) Estudio agronómico y autoecológico del chile piquín (Capsicum annuum L. var. glabrisculum Heiser y Pickersgill) en el área central de Nuevo León. Tesis ITESM. División de Ciencias Agropecuarias y Marítimas. Monterrey, NL, México.

González GM, Villalón MH, Mata BE, Soto RJM, Garza OF (2009) Determinación del Tamaño de Fruto como Parte de las Características Morfológicas del Chile Silvestre "Piquín" (Capsicum annuum L. var. aviculare Dieb.) en diferentes localidades del estado de Nuevo León. Memoria IX Congreso Mexicano de Recursos Forestales. Oaxaca, México.

Jura do E, Aguirre O, Flores J, Navar J, Villalón H, Wester D (2000) Germination in tamaulipan thornscrub of north-eastern Mexico. Journal of Arid Environments 46: 413-424. doi:10.1006/jare.2000.0684. 
Medina MTH, Villalón MM, Lara VG, Gaona GL, Trejo H \& A, Cardona E (2000) El Chile Piquín del Noreste de México. CONACYT, UAT y UANL. Cd. Victoria, Tamaulipas, México, 34

Medina MTH, Villalón MH, Rodríguez BLA, Pozo CO, Ramírez MMM, Lara VM, Trejo HL, Cardona EA, Mora OA, Carreón A (2003) Estudio poblacional y manejo agroforestal de chile piquín (Capsicum annuum L. var. aviculare) en el noreste de México. I.er Simposio Regional sobre Chile Piquín: Avances de Investigación en Tecnología de Producción y Uso Racional del Recurso Silvestre. Río Bravo, Tamaulipas, México.

Medina-Martinez TC (2007) Socioeconomía y ecología del chile piquín en Tamaulipas, México. Cuarta Convencion Mundial del Chile. Queretaro, Qerétaro, México.

Medina MT (2010) Manejo integral del manejo del chile piquín. Ciencia Uat, Ciudad Victoria Tamaulipas, México. $1: 28-29$

Pérez CMS (2009) Distribución, Medio Ambiente y Riesgos de Contaminación Genética y Pérdida de Hábitat de los Chiles Silvestres (Capsicum spp.) en México. Thesis de Maestría Centro de Ciencias Agropecuarias, Universidad Autónoma de Aguascalientes. Jesús María, Agua scalientes, México.

Pozo CO, Ramírez MM (2003) Diversidad e importancia de los chiles silvestres. I.er Simposio Regional sobre Chile Piquín: Avances de Investigación en Tecnología de Producción y Uso Racional del Recurso Silvestre. INIFAP. Río Bravo, Tamaulipas, México, 1:134-146.

Pérez PF, Villalón MH, Soto RJM, Ramírez MM, Garza OF, Carrillo PA (2009) Determinación de las Características Físicas de Unidades de Medición de Semillas de Chile Silvestre "Piquín" (Capsicum annuum L. var. aviculare dierb.) de diferentes localidades del Estado de Nuevo León. Memoria IX Congreso Mexicano de Recursos Forestales. Oaxaca, Oaxaca, México.

Ramírez-Meráz M, Villalon-Mendoza H, Aguilar-Rincón VH, Corona-Torres T, Latournerie-Moreno L (2015) Morphological characterization of wild and semi-domesticated peppers in Mexico's Huasteca region. AGRO Productividad 7 : 9-16.

Rojas SR (1998) Guía para realizar investigaciones sociales. Edit. Plaza y Valdés Editores. 30a . Edición. México, D.F., México.

Secretaría de Economía (2005) Estudio de mercado para Identificar la potencialidad de exportación del Chile piquín en escabeche en el mercado hispano del medio Oeste de los Estado Unidos de Norteamérica. Aporcede AC, México.

Villalón MH, Garza OF, Soto RJM, Medina MT, Ramírez MM, López de LR, Carrillo PA (2009) Aprovechamiento y manejo del chile silvestre "piquín" (Capsicum annuum L. var. aviculare Dierb.) en el Parque Cumbres de Monterrey. Memorias del VII Congreso Nacional Sobre Áreas Naturales Protegidas de México. San Luis Potosí, México 1:76-81.

Villalón MH, Medina Martínez T, Ramírez Meráz M (2013) Factores de calidad de la semilla de chile silvestre (Capsicum annuum L. var. glabriusculum). Quality factors of wild chilli pepper (Capsicum annuum L. var. glabriusculum) seeds. Revista Mexicana de Ciencias Forestales. INIFAP 4:182-187.

Villalon-Mendoza H, Medina-Martinez T, RamirezMeraz M, Urbina - Sandra ES, Maiti R (2014) Factors Influencing the Price of Chile piquin wild chilli (Capsicum annuum L. var. glabriusculum) of North-east Mexico. International Journal of Bio-resource and Stress Management 5:128-131. doi : 10.5958/j.0976-4038.5.1.025. 